\title{
Intestinal parasitosis among Kara and Kwego semi- pastoralist tribes in lower Omo Valley, Southwestern Ethiopia
}

\author{
Tilahun Teklehaymanot
}

\begin{abstract}
Background: Survey of intestinal parasites provides information about the burden of parasites in a community and helps in making decisions for intervention. Nevertheless, such information on the communities living in the Lower Omo Valley is scanty.

Objective: To study the prevalence of intestinal parasitosis among semi-pastoralist tribes in Lower Omo Valley, Southwestern Ethiopia.

Methods: A cross-sectional parasitological survey was conducted on Kara and Kwego semi-pastoralist tribes between January and March 2006. Participants in the study were selected randomly from list of huts and makeshift huts using random numbers. Stool specimens were examined microscopically for the presence of parasite eggs or larvae/cysts using formol-ether concentration method.

Results: Nine intestinal parasites were identified: Entamoeba coli, Entamoeba histolytica/dispar, Giardia lamblia, Iodamoeba buetschlii, Ascaris lumbricoides, Trichuris trichiura, Hookworms, Strongyloides stercoralis and Schistosoma mansoni. The difference in the rates of intestinal parasitic infection between Kara and Kwego is slightly significant $(\mathrm{p}=0.04)$, and between females and males within Kara as well within Kwego was not significant $(p>$ 0.05 ). Only one individual was positive for $S$. mansoni in each tribe. A single parasitic infection was more prevalent than multiple parasitic infections.

Conclusion: Controlling measures including health education are recommended to reduce morbidity and transmission of intestinal parasitic infection among these tribes where health services are at best inadequate for most and entirely absent. [Ethiop.J.Health Dev. 2009;23;(1):57-62]
\end{abstract}

\section{Introduction}

Intestinal parasitic infections, as in many developing counties, are common in Ethiopia and cause serious public health problems such as malnutrition, anaemia and growth retardation as well as higher susceptibility to other infections (1). A report by the Ethiopian Ministry of Health indicated that helminthiasis is a leading cause of outpatient morbidity (2).

The survey on prevalence of intestinal parasites provides information concerning the burden of parasites in a community, enables to predict risks for communities under consideration and decisions to be made as to the need for intervention (3). However, the information on the general prevalence and etiology of intestinal parasitic infection and surveillance data on the health status of the communities living in the remotest and inaccessible part of the southwestern Omo Valley is scanty. So far, there is only one evidence that indicates undertakings of survey on prevalence of intestinal parasites in Omo National Park of Southwest Ethiopia (4) and this is the first crosssectional survey of intestinal parasitosis amongst Kara (Karo) and Kwego (Muguji) semi-pastoralist tribes in the Lower Omo Valley.

The Kara and Kwego tribes found in the bank of Omo River in the remotest part of lower Omo Valley. They were originally pastoralists and hunter-gatherers. However, at present, they also cultivate sorghum and maize on the shore of the Omo River as it retreats. There is no developed infrastructure including latrine and potable water, which they rely on Omo River for their domestic uses (5).

The distribution and prevalence of various intestinal parasitosis in Ethiopia differ from region to region because of several environmental, social and geographical factors (6). Hence, the present investigation was aimed at assessing prevalence of intestinal parasitic infections in the dry arid lowland among the Kara and Kwego tribes. It is believed that the information generated by this study will serve as baseline data to understand the prevalence, distribution and epidemiology of intestinal parasites and against which the future impact of development schemes on health can be compared besides its use as reference for implementation of controling measures.

\section{Methods}

Study Areas: A cross-sectional parasitological survey was carried out on Kara and Kwego tribes between January and March 2006 in Lower Omo River Valley located at about $900 \mathrm{~km}$ from Addis Ababa (Fig. 1). The area is dry 'kola' to dry 'bereha' (dry arid lowland) with mean annual rainfall of $400 \mathrm{~mm}$ to $600 \mathrm{~mm}$ and mean annual temperature of $20.1^{\circ} \mathrm{C}$ to $27.5^{\circ} \mathrm{C}$. The Kara tribe resides in three locations: Lebok (403.26 m.a.s.1, N $05^{\circ}$ 22', E $36^{0} 12^{\prime}$ ), Duss (406.30 m.a.s.1, N $05^{0} 16^{\prime}$, E $36^{\circ}$ $12^{\prime}$ ), and Kortcho (433.13 m.a.s.l, N $05^{\circ} 11^{\prime}$, E $\left.36^{\circ} 12^{\prime}\right)$ on the eastern bank of the Omo River in Hammer

Aklilu Lemma Institute of Pathobiology, Addis Ababa University, P.O. Box 1176, Tel: +251-112-763091, Fax: +251-

112-755296, E-mail tilahunmt@yahoo.com, Addis Ababa, Ethiopia 
Woreda. The Kwego tribe lives in six locations on western bank of Omo River in Kuraz Woreda. Kuchuru has high densely population with permanent residents

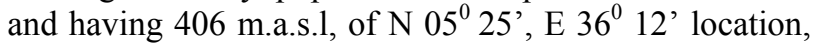
which is about $42 \mathrm{~km}$ from Kangaton. There were no educational and health facilities in the area during data collection period.

Study Subjects: The total population of Kara tribe (1472) and Kwego tribe (584) was considered as a source of sample population for the study. The size of the sample was calculated using the general prevalence formula ( 7 , 8 ) and considering 95\% confidence interval precision of $5 \%$, and assuming the prevalence of intestinal parasitosis to be $80 \%$. The estimated sample size $\left(\mathrm{n}_{\mathrm{inf}}=246\right)$ was converted to estimate sample size of finite population (N): 233 for Kara, 191 for Kwego. The study subjects were sampled using random numbers, which were generated using Microsoft Excel 2003, from list of huts and makeshift huts at each study location.

Stool Collection and Examination: Fresh stool samples were collected from the study subjects and examined for parasite eggs or larvae/cysts. Labelled clean stool cups containing $10 \mathrm{ml}$ of $10 \%$ formalin, toilet tissue paper and clean pieces of applicator sticks were distributed to selected participants to procure stool specimens. Name, sex, age and source of water for domestic purposes of each participant were registered to properly handle their stool specimens. The stool samples were further processed by using a formol-ether concentration method (9) and then examined under $10 \mathrm{X}$ and $40 \mathrm{X}$ microscope objectives by skilled technicians at the Aklilu Lemma
Institute of Pathobiology, Addis Ababa University.

\section{Data Analysis}

The percentage of prevalence of the intestinal parasites and the Chi-square test $(\alpha=0.05)$ were calculated using Microsoft Excel 2007.

Ethical Consideration: The study was part of epidemiological survey of Schistosomiasis Project of the Aklilu Lemma Institute of Pathobiology that has been ethically approved by the Ethical Committee of the institute. Prior to the collection of samples, permission from the South Omo Zone Administration Office and verbal consents from each respondent were obtained. Positive individuals for intestinal helminths including schistosomiasis were treated with mebendazole and praziquantel under the supervision of a health professional. Since this diagnosis was only based on detection of cysts, protozoan infections were not treated.

\section{Results}

About 201 Kara tribes $($ Female $=72$, Male $=129)$ and 200 Kwego tribes $($ Female $=108$, Male $=92)$ brought fresh stool samples. However, 32 individuals from Kara were not willing to submit their samples and were excluded from the study, and nine more individuals were sampled in the Kwego tribe. The females' age of the sampled population of Kara tribes ranged from 3 to 50 years $($ median $=17.5)$ and Kwego tribes ranged from 1 to 81 years (median=15.5). The males' age of the sampled population of Kara tribes ranged from 4 to 50 years (median $=19)$, and Kwego tribes ranged from 1 to 59 years $($ median $=10)$.

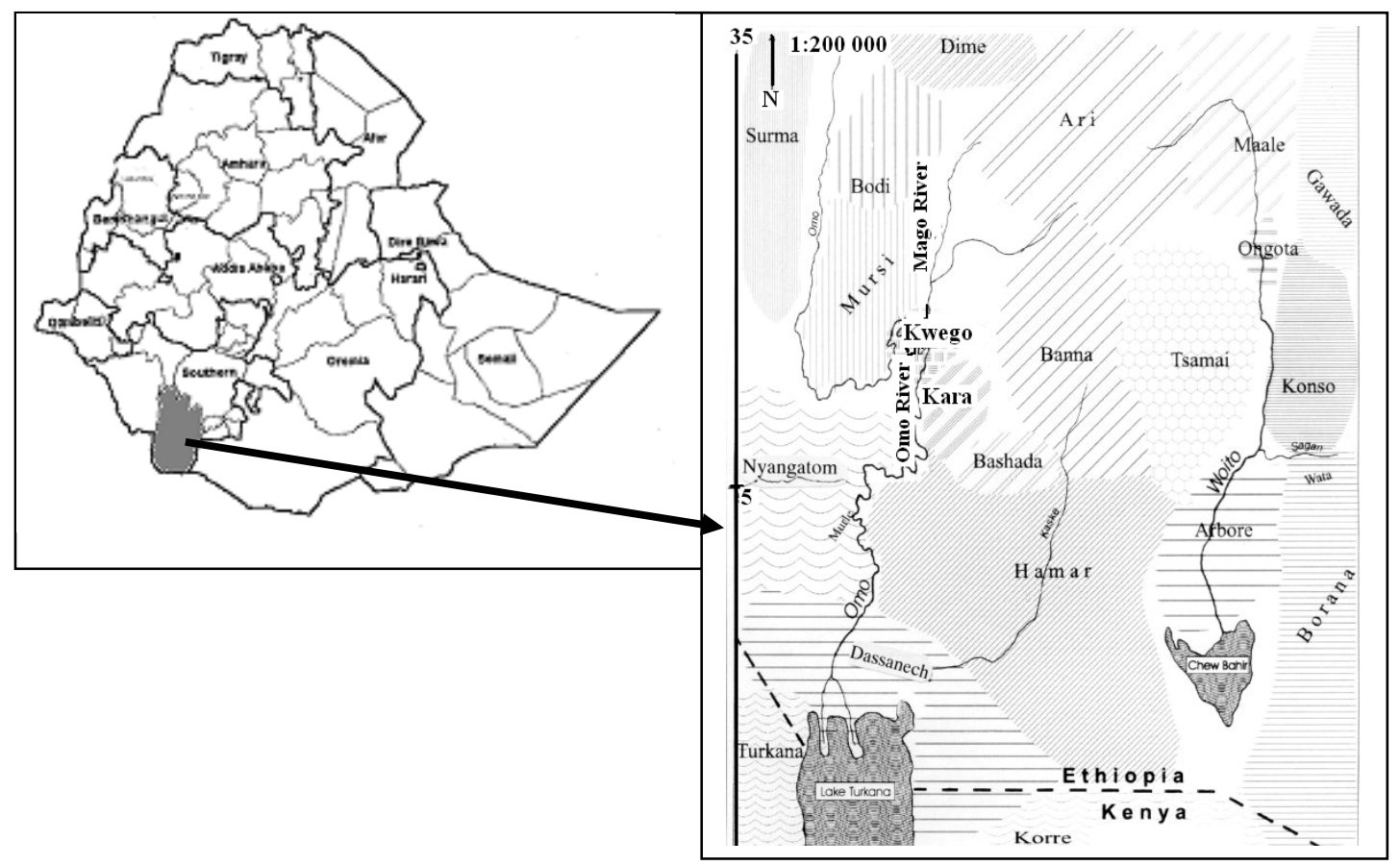

Figure 1 Map of the study sites in Lower Omo Valley, Southwestern Ethiopia, 2006 
Nine intestinal parasites were identified using formolether concentration method: Entamoeba coli, Entamoeba histolytica/dispar, Giardia lamblia, Iodamoeba buetschlii, Ascaris lumbricoides, Trichuris trichiura, Hookworms, Strongyloides stercoralis and Schistosoma mansoni (Table 1). The overall prevalence of intestinal parasitic infection is $104(51.7 \%)$ in Kara and 83(41.5\%) in Kwego and there is a slight difference in the prevalence of intestinal parasitic infection between Kara and Kwego tribes $(\mathrm{p}=0.04)$.
The number of females infected among Kara was $39(54.2 \%)$ and male was $65(50.4 \%)$ and females among Kwego tribe were 49 (45.4\%) and males were 34 (37\%). The prevalence of the intestinal infection was not different between females and males within Kara $(\mathrm{p}=$ $0.607)$ as well within Kwego $(p=0.228)$. In both tribes, the prevalence was higher among individuals younger than 30 years than above (Fig. 2) and the rate of infection between Kara's and Kwego's age groups was not significant $(\mathrm{p}=0.056)($ Table 2,3$)$.

Table 1: Distribution of intestinal parasites in relation to sex among Kara and Kwego semi-pastoralist tribes in Lower Omo Valley, Southwestern Ethiopia, 2006

\begin{tabular}{|c|c|c|c|c|}
\hline \multirow[t]{2}{*}{ Types of Parasites } & \multicolumn{2}{|c|}{ Kara } & \multicolumn{2}{|c|}{ Kwego } \\
\hline & $\begin{array}{l}\text { Male }(n=129) \\
\text { Negative }=64 \\
\text { No (\%) }\end{array}$ & $\begin{array}{l}\text { Female }(n=72) \\
\text { Negative }=33 \\
\text { No (\%) }\end{array}$ & $\begin{array}{l}\text { Male }(n=92) \\
\text { Negative }=58 \\
\text { No (\%) }\end{array}$ & $\begin{array}{l}\text { Female }(n=108) \\
\text { Negative }=59 \\
\text { No }(\%)\end{array}$ \\
\hline \multicolumn{5}{|l|}{ Protozoans } \\
\hline E. coli & $17(13.2)$ & $7(9.7)$ & $16(17.4)$ & $19(17.6)$ \\
\hline E. histolytica/dispar & $2(1.6)$ & $1(1.4)$ & $0(0.0)$ & $0(0.0)$ \\
\hline Giardia lamblia & $25(19.4)$ & 14(19.4) & 1(1.1) & $3(2.8)$ \\
\hline I. buetschlii & $3(2.3)$ & $2(2.8)$ & $9(9.8)$ & 12(11.1) \\
\hline \multicolumn{5}{|l|}{ Helminths } \\
\hline A. lumbricoides & $15(11.6)$ & $9(12.5)$ & $11(12.0)$ & $14(13.0)$ \\
\hline T. trichiura & $18(14.0)$ & $15(20.8)$ & $13(14.1)$ & $18(16.7)$ \\
\hline Hookworm species & $8(6.2)$ & $1(1.4)$ & $0(0.0)$ & $5(4.6)$ \\
\hline S. stercoralis & $0(0.0)$ & $1(1.4)$ & $0(0.0)$ & $3(2.8)$ \\
\hline S. mansoni & $1(0.8)$ & $0(0.0)$ & $0(0.0)$ & $1(0.9)$ \\
\hline
\end{tabular}

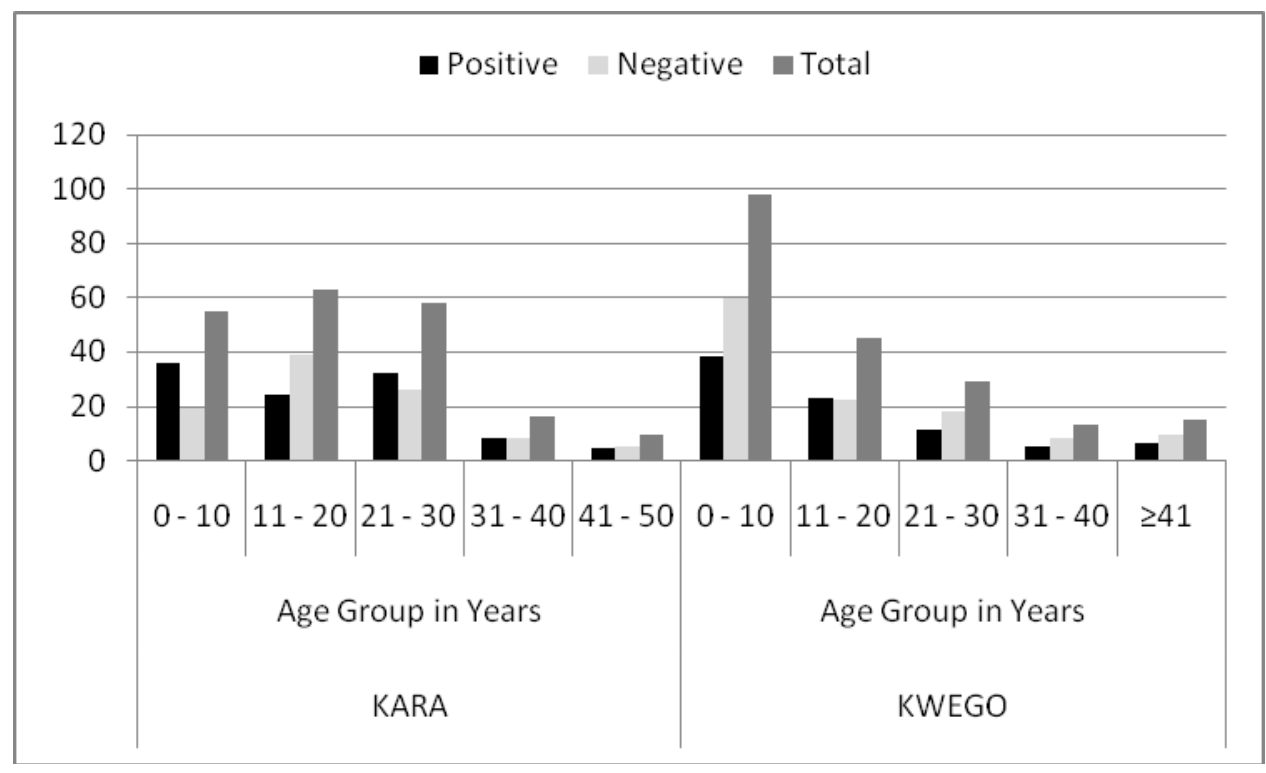

Figure 2: Overall prevalence of intestinal parasites infection in Kara and Kwego Tribe by age groups, 2006 
Table 2: Distribution of Intestinal parasites among different age groups in Kara semi-pastoralist tribes in Lower Omo Valley, Southwestern Ethiopia, 2006

\begin{tabular}{|c|c|c|c|c|c|}
\hline \multirow[t]{2}{*}{ Types of Parasites } & \multicolumn{5}{|c|}{ Age Group in Years } \\
\hline & $\begin{array}{l}3-10 \quad(n=55) \\
\text { Negative }=19 \\
\text { No }(\%)\end{array}$ & $\begin{array}{l}11-20 \quad(n=63) \\
\text { Negative }=39 \\
\text { No }(\%)\end{array}$ & $\begin{array}{l}21-30 \quad(n=58) \\
\text { Negative }=26 \\
\text { No (\%) }\end{array}$ & $\begin{array}{l}31-40 \quad(n=16) \\
\text { Negative }=8 \\
\text { No (\%) }\end{array}$ & $\begin{array}{l}41-50 \quad(n=9) \\
\text { Negative }=5 \\
\text { No (\%) }\end{array}$ \\
\hline \multicolumn{6}{|l|}{ Protozoans } \\
\hline Entamoeba coli & $10(18.2)$ & $3(4.8)$ & $8(13.8)$ & $2(12.5)$ & 1(11.1) \\
\hline $\begin{array}{l}\text { Entamoeba } \\
\text { histolytica/dispar }\end{array}$ & $2(3.6)$ & $0(0.0)$ & $0(0.0)$ & $0(0.0)$ & 1(11.1) \\
\hline Giardia lamblia & $19(34.5)$ & $7(11.1)$ & $10(17.2)$ & $3(18.8)$ & $0(0.0)$ \\
\hline Iodamoeba buetschlii & $2(3.6)$ & $1(1.6)$ & $1(1.7)$ & $0(0.0)$ & 1(11.1) \\
\hline \multicolumn{6}{|l|}{ Heliminths } \\
\hline A. lumbricoides & $5(9.1)$ & $9(14.3)$ & $9(15.5)$ & $1(6.3)$ & $0(0.0)$ \\
\hline T. trichiura & $14(25.5)$ & $7(11.1)$ & $7(12.1)$ & $3(18.8)$ & $2(22.2)$ \\
\hline Hookworms & $4(7.3)$ & $2(3.2)$ & $2(3.4)$ & $1(6.3)$ & $0(0.0)$ \\
\hline S. stercoralis & $1(1.8)$ & $0(0.0)$ & $0(0.0)$ & $0(0.0)$ & $0(0.0)$ \\
\hline S. mansoni & $0(0.0)$ & $0(0.0)$ & $1(1.7)$ & $0(0.0)$ & $0(0.0)$ \\
\hline
\end{tabular}

Table 3: Distribution of Intestinal parasites among different age groups in Kwego semi-pastoralist tribes in Lower Omo Valley, Southwestern Ethiopia, 2006

\begin{tabular}{|c|c|c|c|c|c|}
\hline \multirow[t]{2}{*}{ Types of Parasites } & \multicolumn{5}{|c|}{ Age Group in Years } \\
\hline & $\begin{array}{l}1-10 \quad(n=98) \\
\text { Negative }=60 \\
\text { No }(\%)\end{array}$ & $\begin{array}{l}11-20 \quad(n=45) \\
\text { Negative }=22 \\
\text { No }(\%)\end{array}$ & $\begin{array}{l}21-30 \quad(n=29) \\
\text { Negative }=18 \\
\text { No }(\%)\end{array}$ & $\begin{array}{l}31-40 \quad(n=13) \\
\text { Negative }=8 \\
\text { No }(\%)\end{array}$ & $\begin{array}{l}\geq 41 \quad(n=15) \\
\text { Negative }=9 \\
\text { No }(\%)\end{array}$ \\
\hline \multicolumn{6}{|l|}{ Protozoans } \\
\hline E. coli & $13(13.3)$ & $12(26.7)$ & $5(17.2)$ & $4(30.8)$ & $1(6.7)$ \\
\hline G. lamblia & $3(3.1)$ & $0(0.0)$ & $1(3.4)$ & $0(0.0)$ & $0(0.0)$ \\
\hline I. buetschlii & $10(10.2)$ & $5(11.1)$ & $3(10.3)$ & $2(15.4)$ & $1(6.7)$ \\
\hline \multicolumn{6}{|l|}{ Helminths } \\
\hline A. lumbricoides & $13(13.3)$ & $6(13.3)$ & $3(10.3)$ & $2(15.4)$ & $1(6.7)$ \\
\hline T. trichiura & 13(13.3) & $9(20.0)$ & $4(13.8)$ & $2(15.4)$ & $3(20.0)$ \\
\hline Hookworms & $1(1.0)$ & $1(2.2)$ & $2(6.9)$ & $1(7.7)$ & $0(0.0)$ \\
\hline S. stercoralis & $1(1.0)$ & $1(2.2)$ & $1(3.4)$ & $0(0.0)$ & $0(0.0)$ \\
\hline S. mansoni & $0(0.0)$ & $0(0.0)$ & $1(3.4)$ & $0(0.0)$ & $0(0.0)$ \\
\hline
\end{tabular}

Only a single individual was positive for Schistosoma mansoni in each tribe. A single parasitic infection was more prevalent than multiple parasitic infections (Table 4). In Kara, out of 85 infected individuals $23(25 \%)$ had co-infection of $T$. trichiura: Eight with G. lamblia followed by seven with $E$. coli, five with A. lumbricoides and three with hookworm. Likewise, in Kwego, out of the total $83(41.5 \%)$ infected individuals $14(17 \%)$ had co-infection of T. Trichiura: ten with E. coli, three with A. lumbricoides and one with hookworm.
Table 4: The prevalence of a single and multiple intestinal parasites infections among Kara and Kwego semi-pastoralist tribes Lower Omo Valley, Southwestern Ethiopia, 2006

\begin{tabular}{lll}
\hline $\begin{array}{l}\text { Combination of } \\
\text { intestinal parasites }\end{array}$ & $\begin{array}{l}\text { Kara } \\
(\mathbf{n = 2 0 1 )}\end{array}$ & $\begin{array}{l}\text { Kwego } \\
(\mathbf{n}=\mathbf{2 0 0})\end{array}$ \\
\hline One & $77(38.3 \%)$ & $51(25.5 \%)$ \\
Two & $22(10.9 \%)$ & $23(11.5 \%)$ \\
Three & $2(1.0 \%)$ & $8(4.0 \%)$ \\
Four & $3(1.5 \%)$ & $1(0.5 \%)$ \\
\hline
\end{tabular}




\section{Discussion}

In this study, nine parasites were identified. The prevalence of intestinal parasitism in $104(51.7 \%)$ of Kara and $83(41.5 \%)$ of Kwego was low comparing different groups of central African forest hunter-gatherers and former hunter-gatherers (semi) nomadic tribes (average $\mathrm{n}=262$ ) where high intestinal parasites loads are reported (10). On the other hand, it is similar to the prevalence of intestinal parasites in the nomadic populations in southern Somalia $(\mathrm{n}=62)$ and Hausas/Fulanis ethnic group in southeast Nigeria $(\mathrm{n}=$ 231), which was diagnosed using formol-ether concentration method $(11,12)$. Relatively low prevalence of infection might be due to the absence of crowding and nomadic way of life. Furthermore, the arid condition of the area could also be one of the factors affecting external larval development.

The nomadic people usually migrate to avoid diseases both for themselves and their animals while their periodic movement may either remove them from contaminated environments or may bring then into contact, often seasonally, with infections. Therefore, the prevalence of parasitic infection in such population may vary in accordance to seasonal migration and encampment location $(11,12)$. These may affect the actual results obtained; leading either to false low or false high prevalence of infection in the area.

The overall prevalence of A. lumbricoides (12.2\%), $T$. trichiura (16.0\%) and hookworms (3.5\%) was similar to the result of a nation-wide study conducted in the low and dry areas of the country $(13,14)$. A. lumbricoides, $T$. trichiura and hookworms, as soil-transmitted helminths, are closely associated with poverty, crowding, and poor sanitation. The use of latrines and conventional washing with soap and water are not common among these tribes, they have poor personal hygiene and poor awareness of health, and disposed their refuse including faeces in the open field.

Omo River is the only source of water for the two tribes in Lower Omo River Valley, it is important to note that this practice makes it necessary to consider the possibility of infection by E. coli (12.2\%) and G. lamblia $(10.7 \%)$. Omo River water is exposed source and it is vulnerable for a variety of types of contamination, not only environmental but also during its transport, usually in non-hygienic conditions.

The tribes living along Omo River refine the turbid Omo River water with root of a plant, Klulup (Maerua subcordata (Gilg.) De Wolf; family Capparidaceae). The water in a pot of 20 to 25 liter size is vigorously stirred using the root of Kulup, which is kept in the pot until the turbid water becomes clear and the sediments settles down. The water, however, shows a slightly yellowish discoloration because of the color from the root (15) and this might be one of the possibilities for the reduction of intestinal parasitic infection compared to studies conducted in south western Ethiopia (4), nevertheless, this needs further investigation.

Schistosoma mansoni (1\%) is found only in two individuals at ages 21 and 30, which the author assumed the cases to be imported. Because, according to Schwartz et al. (16), after three rafting trips in the Omo River, out of 44 individuals about 28 (76\%) were infected with $S$. mansoni in 1993. The diagnosis was based on FASTenzyme-linked immunosorbent assay with confirmation by immunoblot. However, other three rafting trip in the Omo River by 1998 did not result in symptomatic infection. Furthermore, the majority of tribes in the area have frequent water contact for different activities such as washing, swimming and for domestic uses; therefore, if schistosome cercariae were available in the Omo River, S. mansoni infection might have been as high as endemic areas in the zone $(4,13,14)$.

In conclusion, the study conducted on the prevalence of intestinal parasites in the two tribes illustrates the health status of the people and the problems that need to be addressed to improve the health and well-being of the people. Controlling measures including health education are recommended to reduce morbidity and transmission of intestinal parasitic infection among these tribes where health services are at best inadequate for most and entirely absent. Furthermore, it is additional information on the epidemiology of parasitic infection in nomad populations, which is limited because of the isolation, and remoteness of many nomad populations.

\section{Acknowledgements}

I am very much grateful to all the local Administrators and communities for their cooperation during the survey. Without their contribution, this study would have been impossible. I would also like to thank the staff of Medical Parasitology Unit of the Aklilu Lemma Institute of Pathobiology, Addis Ababa University, for their assistance and the Austrian Development Cooperation, Addis Ababa for the financial support to conduct this study.

\section{References}

1. Tedla S. Intestinal helminthiasis of man in Ethiopia. Helminthologia. 1986;23:43-48.

2. MOH. Health and Health Related Indicators. Planning and Programming Department, FMOH, 2004, Addis Ababa, Ethiopia; 2003/04.

3. Montresor A, Crompton DWT, Bundy DAP, Hall A, Savioli L. Guidelines for the evaluation of soiltransmitted helminthiasis and schistosomiasis at community level, WHO, Geneva, 1998;1-49.

4. Fuller GK, Lemma A, Haile T. Schistosomiasis in Omo National Park of Southwest Ethiopia. Am. J. Trop. Med. Hyg. 1979;28(3):526-530. 
5. Genetu B. Socio-Economic and Demographic Profile of South Omo Zone, SNNPR, Jinka, Ethiopia, 2005;1-49.

6. Kloos H, Tesfa-Michael TY. Intestinal parasitism. In: The Ecology of Health and Disease in Ethiopia. Edited by Kloos H, Zein ZA. Boulder, West View Press, San Franciscon, 1993:223-233.

7. Bartlett JE, Kotrlik JW, Higgins CC. Organizational Research: Determining Appropriate Sample Size in Survey Research, Information Technology, Learning, and Performance Journal, 2001;(1):43-50.

8. Cochran, W. G. Sampling techniques (3rd ed.).New York: John Wiley \& Sons, 1977:75-76.

9. Ritchie LS: An ether sedimentation technique for routine stool examination. Bull US Army Med Dept. 1948;8: 326-334.

10. Ohenjo N, Willis R, Jackson D, Nettleton C, Good $\mathrm{K}$, Mugarura B. Health of Indigenous people in Africa, The Lancet 2006;367(9526):1937-1946.

11. Sheik-Mohamed A, Velema JP. Where health care has no access: the nomadic populations of subSaharan Africa Tropical Medicine and International Health 1999;4 (10):695-707.
12. Anosike JC, Nwoke BEB, Onwuliri COE, Obiukwu CE, Duru AF, Nwachukwu MI, Chinyere N. Ukaga CN, Joseph C. Uwaezuoke JC, Uduji OS, Amajuoyi OU, Nkem BI. Prevalence of parasitic diseases among nomadic fulanis of South-eastern Nigeria, Ann Agric Environ Med 2004;11:221-225.

13. Birrie H, Erko B, Tedla S. Intestinal helminthic infections in the southern Rift Valley of Ethiopia with special reference to schistosomiasis. East Afr Med J. 1994;71(7):447-452.

14. Birrie H, Ayele T, Tedla S, Abebe F. Transmission of Schistosoma mansoni in three ecological settings in Ethiopia. Ethiop J Health Dev. 1993;7:63-69.

15. Göttsch E. Purification of turbid surface water by plants in Ethiopia. Walia, 1992;14:23-28.

16. Schwartz E, Kozarsky P, Wilson M, Cetron M: Schistosome infection among river rafters on Omo River, Ethiopia. J Travel Med. 2005;12(1):3-8 